\title{
Leptin and the intervertebral disc: a biochemical link exists between obesity, intervertebral disc degeneration and low back pain-an in vitro study in a bovine model
}

\author{
Anand H Segar ${ }^{1,2,3}$. . Jeremy C T Fairbank ${ }^{1,2}$. Jill Urban ${ }^{3}$
}

Received: 20 February 2018 / Accepted: 19 September 2018 / Published online: 15 October 2018

(c) The Author(s) 2018

\begin{abstract}
Purpose The aim of this study was to identify the effects of leptin upon the intervertebral disc (IVD) and to determine whether these responses are potentiated within an environment of existing degeneration. Obesity is a significant risk factor for low back pain (LBP) and IVD degeneration. Adipokines, such as leptin, are novel cytokines produced primarily by adipose tissue and have been implicated in degradative and inflammatory processes. Obese individuals are known to have higher concentrations of serum leptin, and IVD cells express leptin receptors. We hypothesise that adipokines, such as leptin, mediate a biochemical link between obesity, IVD degeneration and LBP.

Methods The bovine intervertebral disc was used as a model system to investigate the biochemical effects of obesity, mediated by leptin, upon the intervertebral disc. Freshly isolated cells, embedded in 3D alginate beads, were subsequently cultured under varying concentrations of leptin, alone or together with the pro-inflammatory cytokines TNF- $\alpha$, IL- $1 \beta$ or IL- 6 . Responses in relation to production of nitric oxide, lactate, glycosaminoglycans and expression of anabolic and catabolic genes were analysed.

Results Leptin influenced the cellular metabolism leading particularly to greater production of proteases and NO. Addition of leptin to an inflammatory environment demonstrated a marked deleterious synergistic effect with greater production of NO, MMPs and potentiation of pro-inflammatory cytokine production.

Conclusions Leptin can initiate processes involved in IVD degeneration. This effect is potentiated in an environment of existing degeneration and inflammation. Hence, a biochemical mechanism may underlie the link between obesity, intervertebral disc degeneration and low back pain.
\end{abstract}

Graphical abstract These slides can be retrieved under Electronic Supplementary Material.

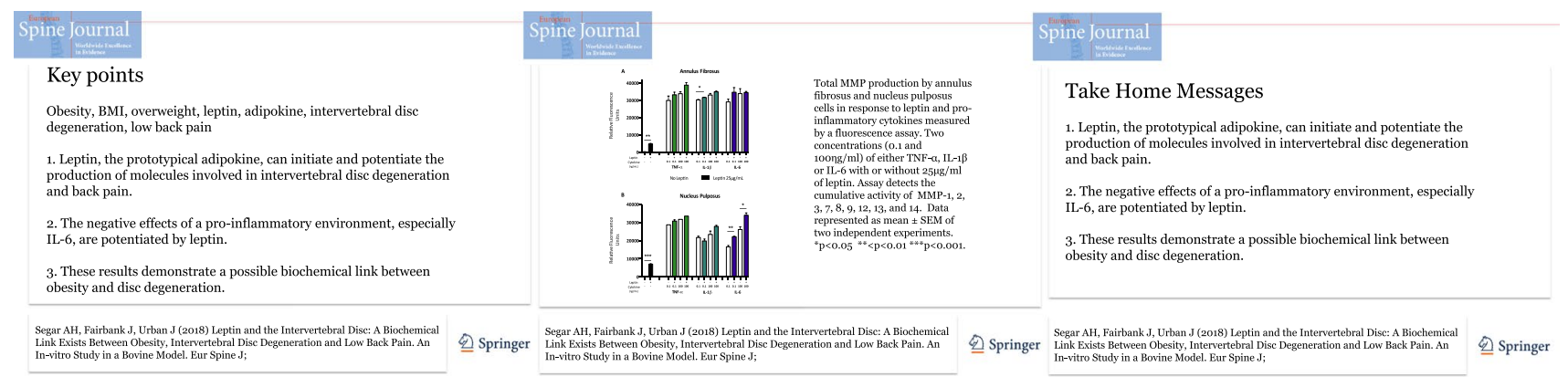

Electronic supplementary material The online version of this article (https://doi.org/10.1007/s00586-018-5778-7) contains supplementary material, which is available to authorized users.

Extended author information available on the last page of the article 
Keywords Obesity $\cdot$ BMI $\cdot$ Overweight $\cdot$ Leptin $\cdot$ Adipokine $\cdot$ Intervertebral disc degeneration $\cdot$ Low back pain

\section{Introduction}

Low back pain (LBP) is the leading cause of years lived with disability, worldwide [1]. While the pathogenesis of low back pain is complex and not well understood, many authors have linked LBP to intervertebral disc (IVD) degeneration [2-4].

Obesity is another public health epidemic, described as one of the most important contributors to the worldwide disease burden [5]. Obesity is associated with an increased risk of cardiovascular disease, type 2 diabetes and cancer [6, 7]. Obesity is also a significant risk factor for musculoskeletal problems such as osteoarthritis [8,9].

Over the past 20 years it has become evident that many of the pathological conditions arising in obese patients involve a systemic low-grade inflammation. Adipose tissue or fat, though once thought to be benign, serving as a source of energy, is now known to be a true endocrine organ producing a variety cytokines, termed adipokines. Leptin, discovered in 1994, is the prototypical adipokine and acts primarily to regulate appetite [10]. It is also the primary biochemical mediator of the inflammatory, degradative and pain-related effects of obesity and, while primarily the product of adipocytes, is also produced by multiple other tissues including cartilages [11-13].

Both biological and clinical evidence implicates leptin in the pathogenesis of osteoarthritis and other musculoskeletal disorders $[10,14]$. While inappropriate mechanical forces and changes in gait are thought to mediate osteoarthritic changes in joints of obese patients, biochemical pathways involving leptin produced by the intracellular fat pad can upregulate degradative enzymes $[14,15]$ in synovium and articular cartilage and lead to local expression of pro-inflammatory cytokines [16].

Obesity is also a risk factor for disc degeneration and low back pain with investigations concentrating on the role of altered body weight and biomechanics. Although leptin and its receptor have been localised in the IVD [13, 17], little is known about their possible roles. Given the similarities between cartilage and the IVD, leptin could mediate similar degradative processes and prove to be a biochemical link between obesity, IVD degeneration and LBP. Indeed, Urquhart et al. [18, 19] found greater fat mass was associated with an increased back pain and reduced disc height and hypothesised biochemical factors as a mediator. Similarly, a large MRI population study showed similar relationship with obesity and disc degeneration [20]. Hence, we hypothesise that leptin, an adipokine, can induce inflammation and degeneration in the IVD and that, as in articular cartilage, the effect is potentiated in a pro-inflammatory environment.

\section{Materials and methods}

\section{Disc cell isolation and culture}

Bovine IVDs appear similar in cell and matrix properties to human discs and were used as a model system [21]. The nucleus pulposus (NP) and annulus fibrosus (AF) of the IVD were dissected from 18- to 24-month bovine tails, obtained from a local abattoir, within $2 \mathrm{~h}$ of slaughter.

IVD cells were isolated separately from the NP and AF by enzymatic digestion using a standard protocol [22]. The cells were then encapsulated in alginate beads to maintain cell phenotype [23-25]. The cells were suspended in a solution of $1.2 \%$ alginate at a concentration of 4 million cells $/ \mathrm{ml}$. This suspension was extruded through a $21 \mathrm{G}$ needle into $102 \mathrm{mM} \mathrm{CaCl}_{2}$ where insoluble calcium alginate beads are formed, encapsulating the cells. Excess $\mathrm{CaCl}_{2}$ was removed by washing the beads thrice with phosphatebuffered saline (PBS). This procedure resulted in spherical alginate beads each of $15 \mu \mathrm{l}$ volume, containing 40,000 cells per bead.

The beads were cultured in DMEM $25 \mathrm{mM}$ Hepes, $1 \mathrm{mM}$ sodium pyruvate, $1000 \mathrm{mg} / \mathrm{L}$ glucose and pyridoxine) at $380 \mathrm{mOsm}$ supplemented with antibiotic-antimycotic solution (2\% v/v) and foetal bovine serum (10\% v/v)] at 1 million cells $/ \mathrm{ml}$ and at $37{ }^{\circ} \mathrm{C}, 100 \%$ humidity in $21 \%$ $\mathrm{O}_{2} / 1 \% \mathrm{CO}_{2}$.

\section{Experimental procedure}

Cells were cultured for $24 \mathrm{~h}$ initially to allow equilibration to the culture system. The cells were then exposed to leptin alone, at a concentration of 5,10 or $25 \mu \mathrm{g} / \mathrm{ml}$, for $48 \mathrm{~h}$ [14]. At the end of the experiment, the media and alginate were stored for later analysis, while RNA was extracted from the cells.

Following a similar protocol, cells were also exposed to a pro-inflammatory cytokine $[\mathrm{TNF}-\alpha$, interleukin (IL)- $1 \beta$ or IL-6] alone, at concentrations of $0.1,1.0,10$ or $100 \eta \mathrm{g} / \mathrm{ml}$, or in combination with leptin at $25 \mu \mathrm{g} / \mathrm{ml}$. This combination of cytokines and leptin aimed to mimic the pro-inflammatory environment described in disc degeneration [26] and herniation [27]. The concentration of $25 \mu \mathrm{g} / \mathrm{ml}$ for leptin was chosen for the pro-inflammatory experiments as this showed the greatest effect in isolated culture. 


\section{Outcome measures}

\section{Biochemical measurements}

Lactate concentrations were measured using a commercially available lactate assay kit following the manufacturer's protocol (Trinity Biotech, Dublin, Ireland). Sulphated GAGs were measured using a modification of the technique described by Farndale [28]. Nitric oxide was measured by the modified Griess reaction [29].

\section{Matrix metalloproteinases}

The activity and relative concentrations of matrix metalloproteinases (MMPs) were measured in the culture supernatant at various time points. Three methods were used.

Gelatin zymography is an electrophoretic technique that allows for substrate-dependent identification of MMP-2 (gelatinase-A) and MMP-9 (gelatinase-B) at the picogram level and was used as described by $\mathrm{Hu}$ [30]. Recombinant human MMP-2 was used as a positive control. Western blotting allowed for visualisation of MMP-1, MMP-3 and MMP-13. Standard protocol was used with exceptions noted below. To improve sensitivity, $100 \mu \mathrm{g}$ of protein was concentrated using StrataClean resin (Agilent Technologies, USA). Recombinant human MMP-1, MMP-3 and MMP-13 western blot standards were used as positive control and prestained standards as a molecular weight marker. Bovine reactive, primary anti-MMP-1, anti-MMP-3 and anti-MMP-13 antibodies at a dilutions of 1:1000, 1:1000 and 1:5000, respectively, were used (Abcam, Cambridge, UK). Chemiluminescence was detected, and protein bands were quantified by densitometry on ImageJ and normalised to the relevant positive standard.

Fluorometric assay was used to quantify total MMPs. The assay is able to detect the presence of activated MMP1, MMP-2, MMP-3, MMP-7, MMP-8, MMP-9, MMP-12, MMP-13 and MMP-14 down to nanogram concentrations. The commercially available SensoLyte 520 Generic MMP Assay Kit was used as per instructions (Anaspec, California, USA). Pro-MMPs were activated immediately prior to performing the assay using $1 \mathrm{mM}$ APMA.

\section{Quantification of gene expression}

Upon completion of the experiment, alginate beads were dissolved by the addition of citrate buffer and centrifuged for $5 \mathrm{~min}$ at $2500 \mathrm{rpm}$ isolating the cells. The supernatant was removed and digested with $2 \mu \mathrm{l}$ of papain at $60{ }^{\circ} \mathrm{C}$ for $24 \mathrm{~h}$. The cells were washed carefully with PBS to remove any carryover citrate buffer, and the ribonucleic acid (RNA) was isolated using the Qiagen RNeasy Mini Kit using the manufacturers protocol (Qiagen, Hilden, Germany). Briefly, cells were lysed using the provided RLT buffer with 2-ME, inactivating RNases and releasing the RNA. Homogenisation, to reduce sample viscosity, was achieved with the QIAshredder. The homogenate was combined with $70 \%$ ethanol and applied to a silica membrane, to which RNA binds. Repeated washing and centrifugation with the provided buffers purified the RNA, which was finally eluted in RNase-/DNase-free water. RNA concentration and purity were assessed using a NanoDrop 1000 spectrophotometer. Samples were only used if the 260:280 ratio was greater than 1.75. Genomic deoxyribonucleic acid (DNA) was eliminated from the RNA by adding precision DNase and heating to $55^{\circ} \mathrm{C}$. This DNAse enzyme has no activity against RNA. Complementary DNA (cDNA) was synthesised from the RNA samples using the nanoScript reverse transcription premix (PrimerDesign, Manchester, UK).

Internal control genes were selected using the validated GeNorm algorithm designed by Vandesompele [31]. In this system, the two most stably expressed genes were EIF2B2 and ACTB. Oligonucleotide primers were designed and validated by PrimerDesign. All PCRs utilised the $2 \times$ Precision Mastermix with SYBR green dye accordingly using the protocol supplied by PrimerDesign. The reaction was read on the ABI Prism 7000 (Applied Biosystems, California, USA). Melting curves were performed at the end of 40 cycles to ensure a single amplification product. All data were analysed using the $2^{-\Delta \Delta \mathrm{Ct}}$ method with statistical analysis performed using Student's $t$ test as described by Schmittgen and Livak [32].

\section{Statistical analysis}

All data are presented as mean \pm standard error of the mean (SEM) of at least three biological replicates $(n \geq 3)$. Comparison across multiple groups was achieved using the two-way analysis of variance (ANOVA) with Bonferroni correction for multiple comparisons. A $p$ value $\leq 0.05$ was considered statistically significant.

\section{Results}

\section{Leptin alone}

\section{Lactate production}

Leptin alone had minimal effect on cellular energy metabolism. In the AF, there was no discernible change in lactate production with increasing leptin concentration. The NP however showed a trend for a fall in metabolism with the increase in leptin concentration, but this did not reach 

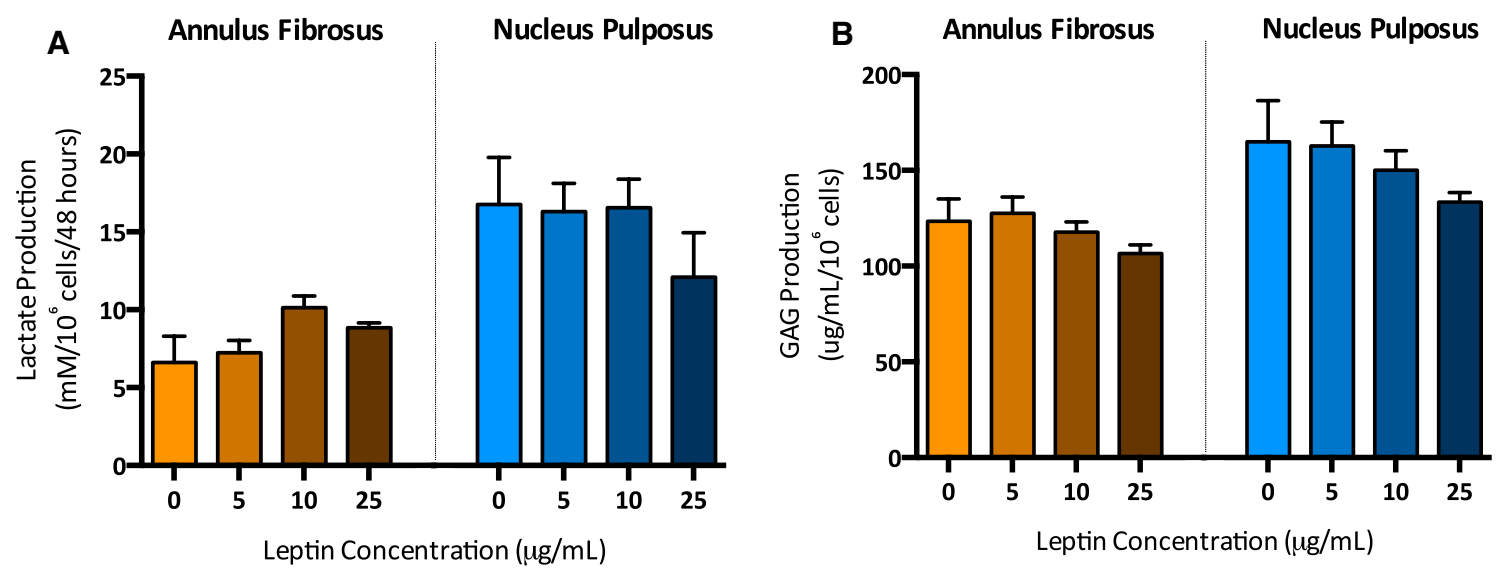

Fig. 1 Lactate (a) and glycosaminoglycan (GAG) (b) production by annulus fibrosus (AF) and nucleus pulposus (NP) cells upon exposure to 3 concentrations of leptin. Assays performed after $48 \mathrm{~h}$ of culture and exposure to leptin. Data represented as mean \pm SEM

statistical significance (Fig. 1a). Lactate production per cell was significantly greater under all conditions for NP than for AF cells.

\section{Glycosaminoglycan (GAG) production}

Figure $1 \mathrm{~b}$ shows the GAG production by both cell types. With increasing leptin, there was a trend for a fall in rates of production, but this was not significant. Compared to the control, AF and NP cells exposed to $25 \mu \mathrm{g} / \mathrm{ml}$ of leptin produced $14 \%$ and $19 \%$ less GAGs, respectively.

\section{Matrix metalloproteinases production measured by zymography and western blotting}

There was a clear dose-dependent increase in MMP-3 and MMP-9 production, by both AF and NP cells, with increases in leptin concentrations (Fig. 2). MMP-1 and MMP-2 did not follow this pattern in the AF and were not detectable in the NP. MMP-13 was not detectable for either cell type at any leptin concentration. Importantly, total MMP production was stimulated markedly with the addition of $25 \mu \mathrm{g} / \mathrm{ml}$ leptin by both AF and NP cells (Fig. 6).

\section{Real-time quantitative polymerase chain reaction}

As leptin at $25 \mu \mathrm{g} / \mathrm{ml}$ had the greatest effect on cell metabolism and protein production, gene expression was quantified in both cell types exposed to this concentration. Figure $3 \mathrm{a}$ shows that for the AF, MMP-7, MMP-11 and TNF- $\alpha$ were all markedly increased relative to the control. For the NP, there was an increase in expression of the ADAMTS-4, ADAMTS-5, IL- 6 and TNF- $\alpha$. There were no changes in the expression of the anabolic genes, aggrecan and collagen and the tissue inhibitor of metalloproteases (TIMPs).
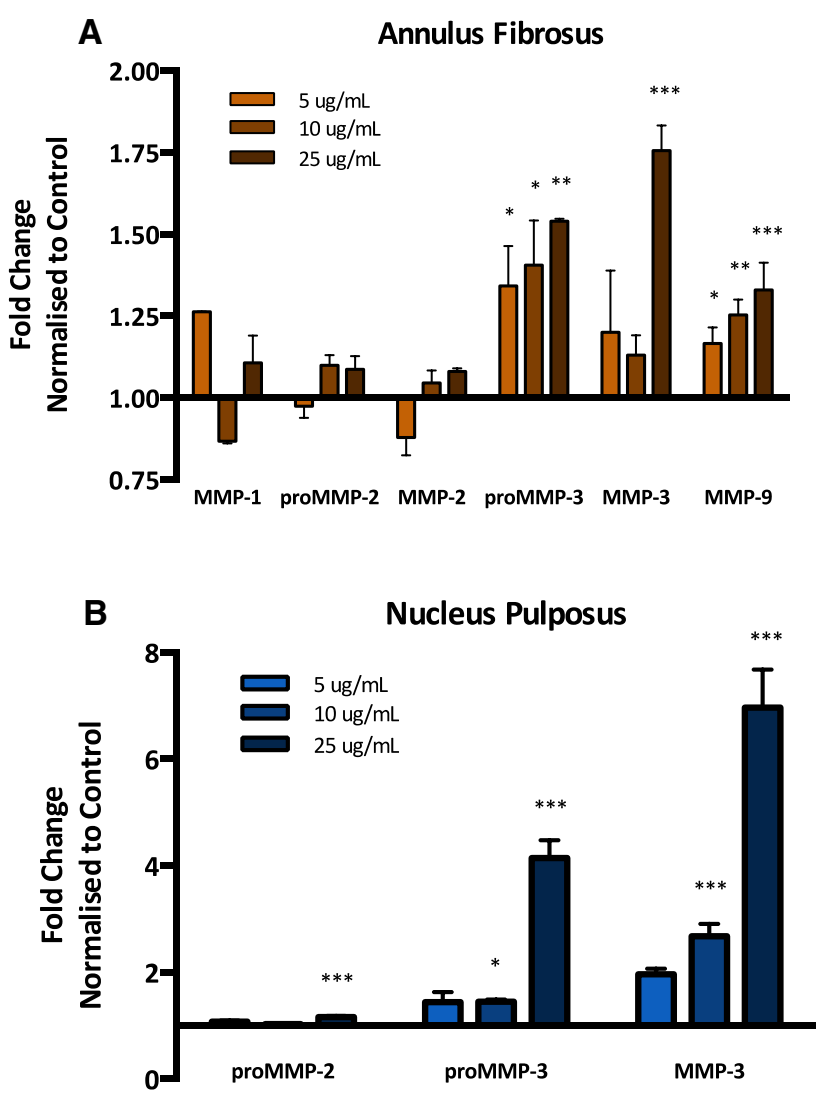

Fig. 2 Effect of leptin concentrations on matrix metalloproteinases (MMPs) produced by annulus fibrosus and nucleus pulposus cells. MMP-2 and MMP-9 measured by gelatin zymography and MMP-1 and MMP-3 quantified by western blotting. At three concentrations of leptin $(5,10$ and $25 \mu \mathrm{g} / \mathrm{ml})$. Intensity normalised and represented as fold change relative to control. MMP-13 was not detected from either NP or AF cells, MMP-1 and MMP-9 not detected from NP cells. Data represented as mean \pm SEM. $* p<0.05 ; * * p<0.01 ; * * * p<0.001$ 

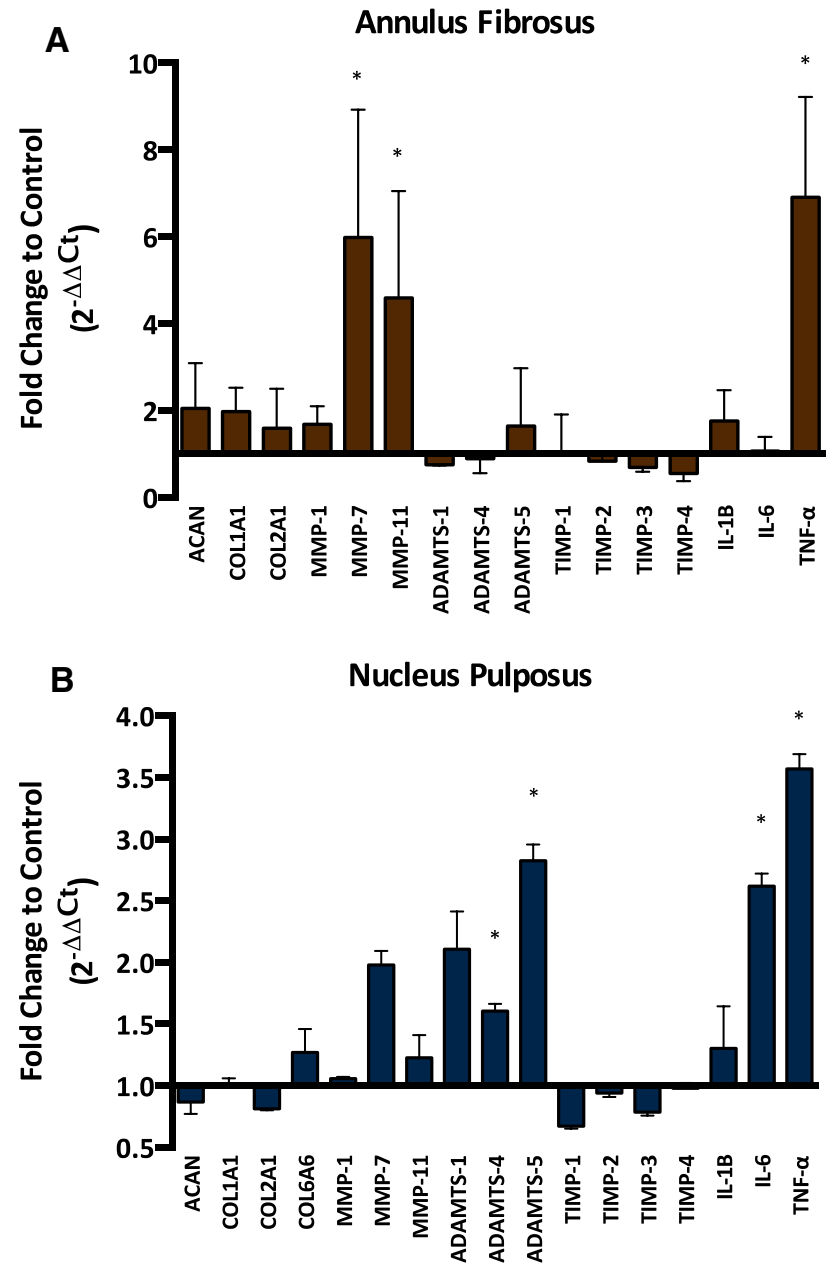

Fig. 3 Gene expression by both annulus fibrosus and nucleus pulposus cells in response to $25 \mu \mathrm{g} / \mathrm{ml}$ leptin normalised to ACTB and EIF2B2 and shown as fold change $2^{-\Delta \Delta \mathrm{Ct}}$ to control. Data represented as mean \pm SEM of three independent experiments. $* p<0.05$

\section{Leptin within a pro-inflammatory environment}

Given the upregulation of the pro-inflammatory cytokines, it was hypothesised that leptin and these cytokines may act synergistically thus potentiating further degradation within an already degenerate environment. Three cytokines, TNF- $\alpha$, IL- $1 \beta$ or IL- 6 , were individually added to the culture system described above along with leptin at $25 \mu \mathrm{g} / \mathrm{ml}$.

\section{Lactate production}

Figure $4 a, b$ shows the combined effect of leptin and TNF- $\alpha$. For the AF, there was a trend for increased energy requirement as TNF- $\alpha$ concentration increased with a small synergistic effect of leptin. Conversely, in the NP, TNF- $\alpha$ was the primary driver of lactate production with no effect of leptin evident. The combination of leptin and IL-1 $\beta$ had very little effect on lactate production in either cell type (Fig. 4c, d) with the difference to the control driven mostly by IL- $1 \beta$. Lactate production rates with IL-6 were increased by the addition of leptin at lower concentrations (0.1 and $1.0 \mathrm{\eta g} /$ $\mathrm{ml})$ in the AF.

\section{Nitric oxide production}

Leptin alone significantly increased nitric oxide (NO) production rates in NP cells (Fig. 5). There was a synergistic increase with both TNF- $\alpha$ and IL- 6 which was more marked at the lower concentrations of TNF- $\alpha$ and at higher concentrations of IL-6. Similar to the results seen with lactate, IL- $1 \beta$ was the primary driver of NO production with most of the effects seen at lower concentrations. NO was not detected in AF cells.

\section{Matrix metalloproteinases production}

Figure $6 \mathrm{a}, \mathrm{b}$ shows the total activated MMP production, as measured by fluorescent assay by both cell types in response to leptin alone, pro-inflammatory cytokines $(0.1$ or $100 \mathrm{\eta g}$ / $\mathrm{ml}$ ) alone or the combination of the two. For both the AF and NP, leptin alone increased the production of total MMPs significantly. Although the fold changes are larger than that seen in Fig. 2, the assay used here is sensitive to a spectrum of MMPs and prior to quantification, pro-MMPs were activated.

\section{Real-time quantitative polymerase chain reaction}

As the greatest synergistic effect was seen with leptin and $0.1 \eta \mathrm{g} / \mathrm{ml} \mathrm{IL}-6$, RNA was isolated from cells exposed to this combination of factors and gene expression assayed by RTqPCR. The only important differences in AF gene expression were with IL-6. In isolation, exposure to IL-6 led to downregulation of IL-6 gene expression, but with the addition of leptin there was a small increase in expression. There was a similar trend in the NP with a twofold increase in IL-6 expression after leptin addition (Fig. 7b). Furthermore, in the NP, there was a significant synergistic upregulation in the expression of TNF- $\alpha$, IL- 6 and ADAMTS-4, by leptin. No change was seen with MMP-2 and MMP-9 and there was a slight non-significant decrease in the expression of TIMP-3.

\section{Discussion}

Our in vitro studies found that the adipokine, leptin, induces a degenerative and inflammatory cascade within the IVD. It upregulated the production of proteases such as the ADAMTSs involved in the degradation of aggrecan and also proteases able to destroy collagen and other matrix 

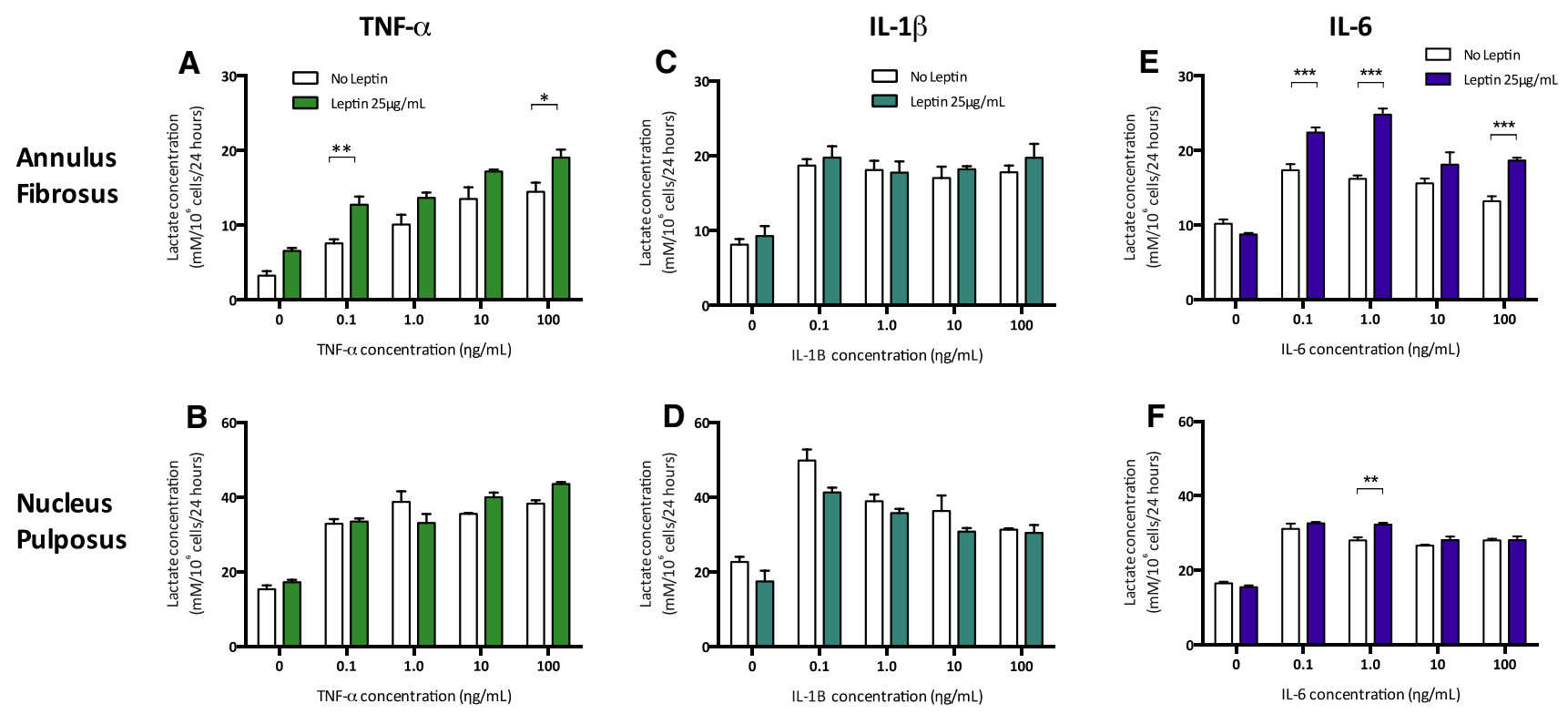

Fig. 4 Lactate production by annulus fibrosus and nucleus pulposus cells in response to leptin and pro-inflammatory cytokines. Four concentrations $(0.1,1.0,10$ and $100 \eta \mathrm{g} / \mathrm{ml})$ of either TNF- $\alpha$, IL- $1 \beta$

or IL-6 with or without $25 \mu \mathrm{g} / \mathrm{ml}$ of leptin. Data represented as mean \pm SEM of three independent experiments. ${ }^{*} p<0.05 * * p<0.01$ $* * * p<0.001$
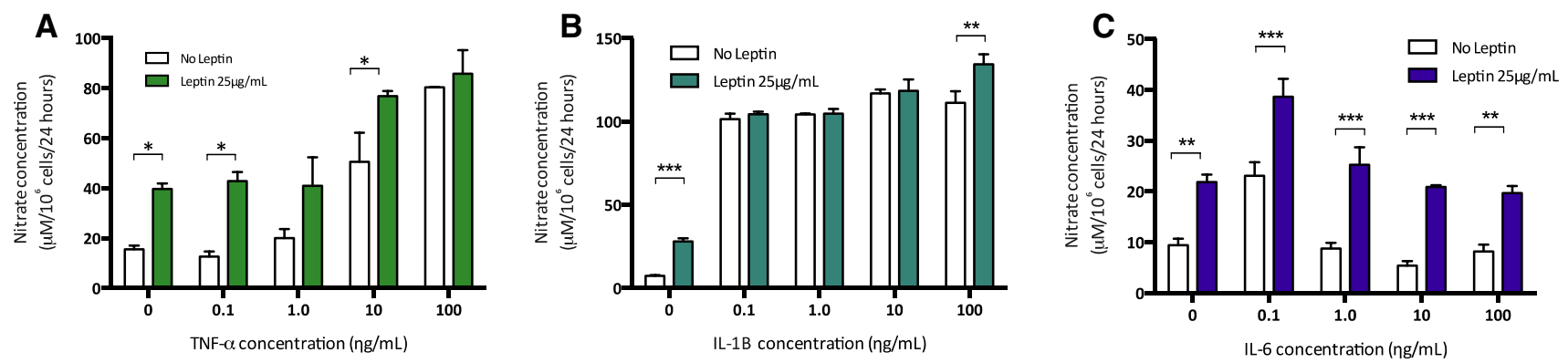

Fig. 5 Nitrate production of nucleus pulposus cells in response to leptin and pro-inflammatory cytokines. Four concentrations $(0.1,1.0,10$ and $100 \eta \mathrm{g} / \mathrm{ml}$ ) of either TNF- $\alpha$, IL- $1 \beta$ or IL- 6 with or without $25 \mu \mathrm{g} /$ $\mathrm{ml}$ of leptin. Nitrate production was only detected by annulus fibrosus

macromolecules at the gene and protein level (Figs. 2, 3). These degradative processes were further stimulated markedly in the NP in a pro-inflammatory environment, particularly in the presence of IL-6 (Figs. 6, 7). Moreover, in the $\mathrm{NP}$, leptin strongly upregulated the expression of the proinflammatory molecules themselves, particularly nitric oxide and the cytokines IL-6 and TNF- $\alpha$ (Figs. 5, 7).

That similar effects of leptin could be of relevance in vivo, has not been demonstrated directly in the disc. However, leptin and its receptors have been identified in degenerate regions of rat and human NP $[13,33]$ and also in AF cells $[12,34]$ which themselves produce leptin throughout the spectrum of degeneration [12]. The results thus indicate that a biochemical pathway involving increased leptin levels cells at a concentration of $100 \eta \mathrm{g} / \mathrm{ml}$ of TNF- $\alpha$ (not shown). Data represented as mean \pm SEM of three independent experiments. $* p<0.05$ $* * p<0.01 * * * p<0.001$

could be involved in the deleterious effects of obesity on disc degeneration and back pain.

The effect of leptin on nitric oxide (NO) production could also be of importance, not only in regard to degeneration [35] but also in relation to back pain. NO has been related to spine-related pain [36] and disc herniation [27]. Leptin alone and in combination with inflammatory mediators markedly increased rates of NO production (Fig. 5).

Of particular importance is the synergy found here between leptin and IL-6. Degeneration of the intervertebral disc is characterised by increased levels of pro-inflammatory cytokines which upregulate degradative processes [26]. Here we found that in the NP, interactions between leptin and IL-6 markedly increased production of MMPs 

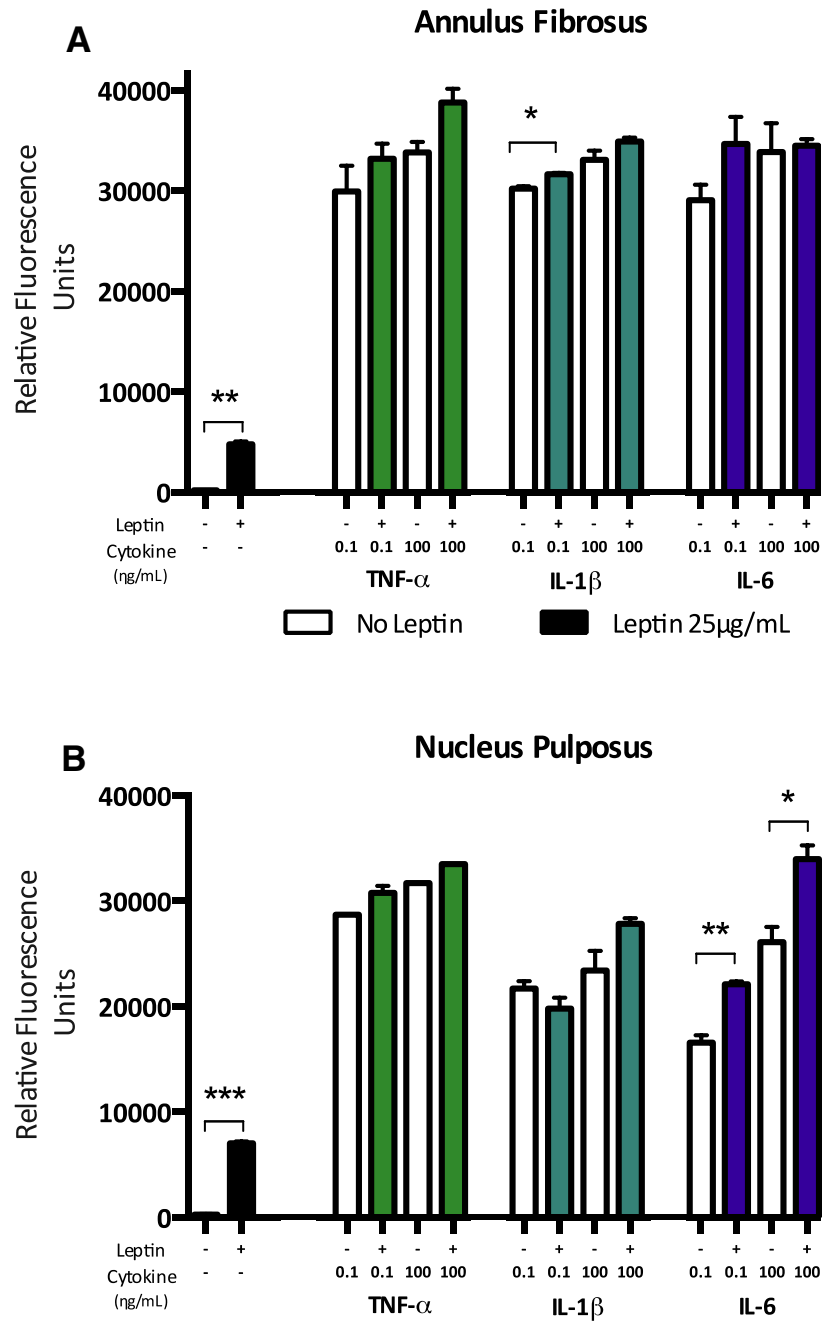

Fig. 6 Total MMP production by annulus fibrosus and nucleus pulposus cells in response to leptin and pro-inflammatory cytokines measured by a fluorescence assay. Two concentrations $(0.1$ and $100 \mathrm{\eta g} / \mathrm{ml})$ of either TNF- $\alpha$, IL- $1 \beta$ or IL- 6 with or without $25 \mu \mathrm{g} / \mathrm{ml}$ of leptin. Assay detects the cumulative activity of MMP-1, MMP-2, MMP3, MMP-7, MMP-8, MMP-9, MMP-12, MMP-13 and MMP-14. Data represented as mean \pm SEM of two independent experiments. $* p<0.05 * * p<0.01 * * * p<0.001$

and also the inflammatory molecules NO, IL-6 and TNF- $\alpha$ (Figs. 5, 7) relative to either IL-6 or leptin alone.

This pathway could act in vivo as leptin and IL-6 colocalise within degenerated IVDs [34]. As shown in other cell types [37-39], leptin can upregulate IL-6 directly via the IL- 6 specific receptor. On the other hand, IL- 6 can control leptin release centrally [40]. Both IL-6 and leptin signal through a class I cytokine receptor; leptin appears to mediate its cytokine-like effects through this homology [41]. However, trying to dissect the exact signalling pathways of leptin is complex with multiple pathways implicated including mitogen-activated protein kinases, protein kinase $\mathrm{B}$, protein kinase $\mathrm{C}$, nuclear factor kappa

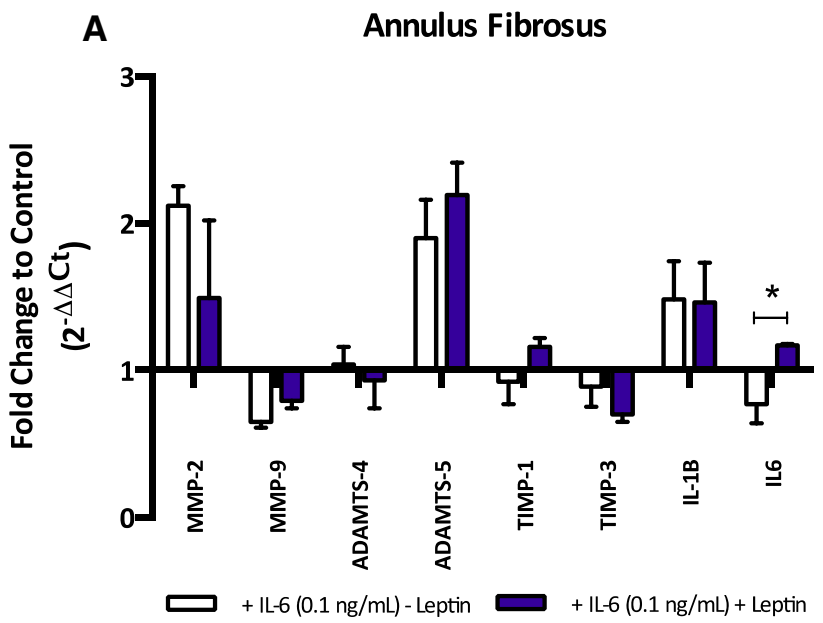

B Nucleus Pulposus

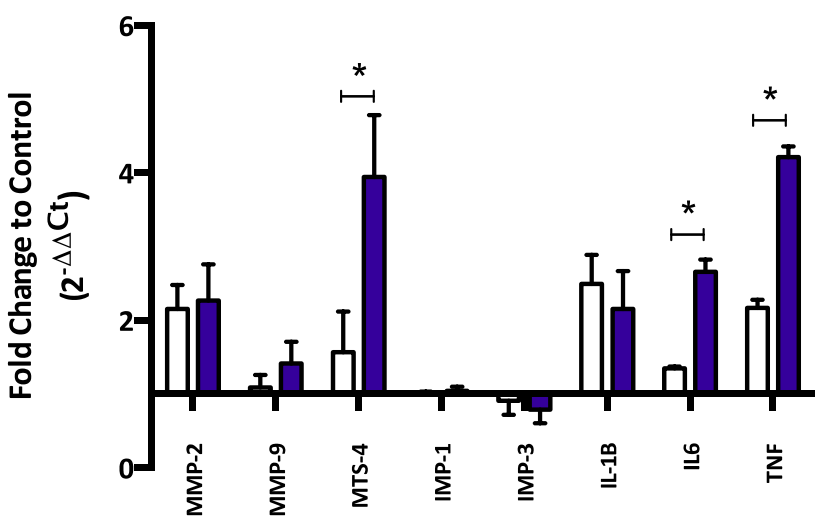

Fig. 7 Gene expression changes in both annulus fibrosus and nucleus pulposus cells in response to leptin and $0.1 \mathrm{\eta g} / \mathrm{ml}$ of IL-6. Normalised to ACTB and shown as fold change $\left(2^{-\Delta \Delta \mathrm{Ct}}\right)$ to control. Data represented as mean \pm SEM of three independent experiments. $* p<0.05$

\section{B, JAK-STAT, cyclins, NO and phosphoinositide 3-kinase} $[16,37,42,43]$.

There are no large population studies investigating the relationship between leptin and back pain or disc degeneration. It is clear in the literature that obesity is associated with both low back and leg pain [44]. However, in smaller studies Urquhart et al. [18, 19] found greater fat mass was associated with increased back pain and reduced disc height and hypothesised biochemical factors as a mediator. Clinically, multiple authors have shown that leptin and other adipokines are mediators of musculoskeletal degeneration. Most recently, Fowler-Brian et al. [45] found half of the effect of increased BMI upon knee OA could be explained by leptin, a strong indictment for deleterious biochemical effects of obesity. This effect was greatest in women, in keeping with a study by Karvonen-Gutierrez et al. [46], which showed a similar independent association. Greater serum and synovial leptin have also been correlated with greater severity of knee and hip OA [47-49]. Other adipokines such as adiponectin 
[50, 51], resistin [52] and visfatin [53] have all been associated with OA. Unfortunately, all but one of these studies are cross sectional and causation cannot be established.

With respect to the lumbar spine, Théron et al. [54] found liposuction of the adipose tissue in atrophied paraspinal muscles was associated with clinical improvement in back pain in $77.5 \%$ of patients studied. This improvement was accompanied by expansion of the paraspinal muscle mass. In this study, clinical improvement could be either improved muscle mass, decreased inflammatory adipose tissue or a combination of both. A recent study by James et al. would point to a biochemical link. The authors showed, in an ovine IVD injury model, an increased proportion of pro-inflammatory M1 macrophages in paraspinal adipose tissue after disc injury, suggesting a local biochemical factors could mediate pain and inflammation in patients [55].

An important consideration of an in vitro study is the extent to which physiological conditions are reproduced. The $\mathrm{AF}$ and NP serve different physiological functions and as a result have a different cellular phenotype. Although culture in alginate beads preserves the phenotype of NP cells, it may not be the most appropriate culture system for AF cells [25]. However, there are distinct differences in phenotype and origin between these cell types with the nucleus cells notochordal and the annulus cells originating from the mesenchyme so the differences observed are unlikely to be only due to the culture conditions.

Furthermore, given the relative paucity of data regarding the IVD and leptin, we used concentrations drawn from the cartilage literature [14, 16], viz. 5-25 $\mu \mathrm{g} / \mathrm{ml}$. Although levels of circulating leptin increase in obesity, they are usually in the range $10-50 \eta \mathrm{g} / \mathrm{ml}$, an order of magnitude lower than used experimentally [10,56-58]. However, studies in on osteoarthritic joints show that local concentrations of leptin may be considerably higher than those found in serum [58]. It thus seems likely that in the disc too, the levels of leptin would be higher than serum levels. Local leptin concentrations could be increased by the IVD cells, which themselves produce leptin [13, 17, 42], and also by adipose tissue adjacent to the disc. Moreover, the levels of leptin required to stimulate disc cells in vivo may be lower than seen in our model bovine system; human NP cells responded to recombinant human leptin at a concentration of only $10 \eta \mathrm{g} / \mathrm{ml}$ $[42,59,60]$, similar to concentrations measured in serum, suggesting that indeed higher leptin levels seen in obesity could mediate disc degeneration and pain.

There is a fledging evidence base as to the role of leptin and the other adipokines in IVD degeneration. In a recent review, Sharma found only 15 in vitro studies investigating this relationship [61]. The author concluded that leptin can have significant effects on IVDs, but cautioned mechanistic and translational work is required to further understand this relationship. Future in vivo studies could look to establish the local and systemic levels of adipokines in patients suffering from low back pain and disc degeneration. We have attempted to identify this with a cross-sectional clinical study investigating serum and paraspinal adipose tissue, the results of which are pending. If a strong association is seen, a larger longitudinal study would be required to further delineate causation.

\section{Conclusion}

In summary, this study found that leptin increases production and expression of degradative and pain-generating molecules by intervertebral disc cells. Crucially, leptin can initiate degenerative processes and within the inflammatory environment seen in degenerate discs, it can potentiate degenerative process, thus supporting a biochemical link in the relationship between intervertebral disc degeneration, back pain and obesity.

Funding The funding was provided by Wishbone Trust of New Zealand, Nuffield Medical Trust, Commonwealth Scholarships Commission and Royal Australasian College of Surgeons

\section{Compliance with ethical standards}

Conflict of interest The authors declare that they have no conflict of interest.

Open Access This article is distributed under the terms of the Creative Commons Attribution 4.0 International License (http://creativeco mmons.org/licenses/by/4.0/), which permits unrestricted use, distribution, and reproduction in any medium, provided you give appropriate credit to the original author(s) and the source, provide a link to the Creative Commons license, and indicate if changes were made.

\section{References}

1. Vos T, Flaxman AD, Naghavi M et al (2012) Years lived with disability (YLDs) for 1160 sequelae of 289 diseases and injuries 1990-2010: a systematic analysis for the Global Burden of Disease Study 2010. Lancet 380:2163-2196. https://doi.org/10.1016/ S0140-6736(12)61729-2

2. Luoma K, Riihimäki H, Luukkonen R et al (2000) Low back pain in relation to lumbar disc degeneration. Spine 25:487-492

3. de Schepper EIT, Damen J, van Meurs JBJ et al (2010) The association between lumbar disc degeneration and low back pain: the influence of age, gender, and individual radiographic features. Spine 35:531-536. https://doi.org/10.1097/brs.0b013e3181aa5b33

4. Cheung KMC, Karppinen J, Chan D et al (2009) Prevalence and pattern of lumbar magnetic resonance imaging changes in a population study of one thousand forty-three individuals. Spine 34:934-940. https://doi.org/10.1097/BRS.0b013e3181a01b3f

5. Haslam DW, James WPT (2005) Obesity. The Lancet 366:11971209. https://doi.org/10.1016/S0140-6736(05)67483-1

6. Goodwin PJ, Stambolic V (2015) Impact of the obesity epidemic on cancer. Annu Rev Med 66:281-296 
7. Guh DP, Zhang W, Bansback N et al (2009) The incidence of comorbidities related to obesity and overweight: a systematic review and meta-analysis. BMC Public Health 25:88

8. Stienstra R, vanDiepen JA, Tack CJ et al (2011) Inflammasome is a central player in the induction of obesity and insulin resistance. Proc Natl Acad Sci USA 13:15324-15329

9. Horng T, Hotamisligil GS (2011) Linking the inflammasome to obesity-related disease. Nat Med 17:164-165

10. Lago F, Dieguez C, Gomez-Reino J, Gualillo O (2007) Adipokines as emerging mediators of immune response and inflammation. Nat Clin Pract Rheumatol 3:716-724. https://doi.org/10.1038/ncprh eum0674

11. Gomez R, Lago F, Gomez-Reino J et al (2009) Adipokines in the skeleton: influence on cartilage function and joint degenerative diseases. J Mol Endocrinol 43:11-18. https://doi.org/10.1677/ JME-08-0131

12. Gruber HE, Ingram JA, Hoelscher GL, Hanley EN Jr (2007) Leptin expression by annulus cells in the human intervertebral disc. Spine J 7:437-443. https://doi.org/10.1016/j.spinee.2006.08.001

13. Zhao C-Q, Liu D, Li H et al (2008) Expression of leptin and its functional receptor on disc cells: contribution to cell proliferation. Spine 33:858-864. https://doi.org/10.1097/BRS.0b013e3181 $8338 \mathrm{e} 5$

14. Hui W, Litherland GJ, Elias MS, et al (2011) Leptin produced by joint white adipose tissue induces cartilage degradation via upregulation and activation of matrix metalloproteinases. Ann Rheum Dis 455-462

15. Koskinen A, Vuolteenaho K, Nieminen R et al (2011) Leptin enhances MMP-1, MMP-3 and MMP-13 production in human osteoarthritic cartilage and correlates with MMP-1 and MMP-3 in synovial fluid from OA patients. Clin Exp Rheumatol 29:57-64

16. Vuolteenaho K, Koskinen A, Kukkonen M et al (2009) Leptin enhances synthesis of proinflammatory mediators in human osteoarthritic cartilage-mediator role of NO in leptin-induced PGE2, IL-6, and IL-8 production. Mediat Inflamm 2009:345838. https ://doi.org/10.1155/2009/345838

17. Gruber HE, Ingram JA, Hoelscher GL, Hanley EN Jr (2007) Leptin expression by annulus cells in the human intervertebral disc. Spine J 7:437-443. https://doi.org/10.1016/j.spinee.2006.08.001

18. Urquhart DM, Berry P, Wluka AE et al (2011) 2011 Young Investigator Award winner: Increased fat mass is associated with high levels of low back pain intensity and disability. Spine 36:1320 1325. https://doi.org/10.1097/brs.0b013e3181f9fb66

19. Urquhart DM, Kurniadi I, Triangto K et al (2014) Obesity is associated with reduced disc height in the lumbar spine but not at the lumbosacral junction. Spine 39:E962-E966. https://doi. org/10.1097/BRS.0000000000000411

20. Samartzis D, Karppinen J, Chan D et al (2012) The association of lumbar intervertebral disc degeneration on magnetic resonance imaging with body mass index in overweight and obese adults: a population-based study. Arthr Rheum 64:1488-1496. https://doi. org/10.1002/art.33462

21. Urban JP, Roberts S (2003) Degeneration of the intervertebral disc. Arthr Res Ther 5:120-138. https://doi.org/10.1186/ar629

22. Cui Y, Yu J, Urban JPG, Young DA (2010) Differential gene expression profiling of metalloproteinases and their inhibitors: a comparison between bovine intervertebral disc nucleus pulposus cells and articular chondrocytes. Spine 35:1101-1108. https://doi. org/10.1097/BRS.0b013e3181c0c727

23. Guo JF, Jourdain GW, MacCallum DK (1989) Culture and growth characteristics of chondrocytes encapsulated in alginate beads. Connect Tissue Res 19:277-297. https://doi.org/10.3109/03008 208909043901

24. Hauselmann HJ, Fernandes RJ, Mok SS et al (1994) Phenotypic stability of bovine articular chondrocytes after long-term culture in alginate beads. J Cell Sci 107(Pt 1):17-27
25. Horner HA, Roberts S, Bielby RC et al (2002) Cells from different regions of the intervertebral disc: effect of culture system on matrix expression and cell phenotype. Spine 27:1018-1028

26. Risbud MV, Shapiro IM (2014) Role of cytokines in intervertebral disc degeneration: pain and disc content. Spine 10:44-56. https:// doi.org/10.1038/nrrheum.2013.160

27. Kang JD, Georgescu HI, McIntyre-Larkin L et al (1996) Herniated lumbar intervertebral discs spontaneously produce matrix metalloproteinases, nitric oxide, interleukin-6, and prostaglandin E2. Spine 21:271-277

28. Farndale R, Buttle D, Barratt A (1986) Improved quantitation and discrimination of sulphated glycosaminoglycans by use of dimethylmethylene blue. Biochim Biophys Acta (BBA) 883:173-177. https://doi.org/10.1016/0304-4165(86)90306-5

29. Miranda KM, Espey MG, Wink DA (2001) A rapid, simple spectrophotometric method for simultaneous detection of nitrate and nitrite. Nitric Oxide 5:62-71. https://doi.org/10.1006/ niox.2000.0319

30. Hu X, Beeton C (2010) Detection of functional matrix metalloproteinases by zymography. J Vis Exp. https://doi.org/10.3791/2445

31. Vandesompele J, DePreter K, Pattyn F et al (2002) Accurate normalization of real-time quantitative RT-PCR data by geometric averaging of multiple internal control genes. Genome Biol 3:research0034. https://doi.org/10.1186/gb-2002-3-7-research00 34

32. Schmittgen TD, Livak KJ (2008) Analyzing real-time PCR data by the comparative CT method. Nat Protoc 3:1101-1108

33. Johnson WE, Eisenstein SM, Roberts S (2001) Cell cluster formation in degenerate lumbar intervertebral discs is associated with increased disc cell proliferation. Connect Tissue Res 42:197-207

34. Koerner JD, Markova DZ, Yadla S et al (2014) Differential gene expression in anterior and posterior annulus fibrosus. Spine 39:1917-1923

35. Liu GZ, Ishihara H, Osada R et al (2001) Nitric oxide mediates the change of proteoglycan synthesis in the human lumbar intervertebral disc in response to hydrostatic pressure. Spine 26:134-141

36. Jacobs LJ, Vo N, Kang JD (2011) Identifying inflammatory targets for biologic therapies for spine pain. PM R 3:S12-S17. https://doi. org/10.1016/j.pmrj.2011.05.003

37. Yang W-H, Liu S-C, Tsai C-H et al (2013) Leptin induces IL-6 expression through OBR1 receptor signaling pathway in human synovial fibroblasts. PLoS ONE 8:e75551. https://doi. org/10.1371/journal.pone.0075551

38. Agrawal S, Gollapudi S, Su H, Gupta S (2011) Leptin activates human B cells to secrete TNF- $\alpha$, IL-6, and IL-10 via JAK2/STAT3 and $\mathrm{p} 38 \mathrm{MAPK} / \mathrm{ERK} 1 / 2$ signaling pathway. J Clin Immunol 31:472-478. https://doi.org/10.1007/s10875-010-9507-1

39. Tang C-H, Tang CH, Lu DY et al (2007) Leptin-induced IL-6 production is mediated by leptin receptor, insulin receptor substrate-1, phosphatidylinositol 3-kinase, Akt, NF-kappaB, and p300 pathway in microglia. J Immunol 179:1292-1302

40. Sadagurski M, Norquay L, Farhang J, D’Aquino K (2010) Human IL6 enhances leptin action in mice. Diabetologia. https://doi. org/10.1007/s00125-009-1580-8

41. Frühbeck $G$ (2006) Intracellular signalling pathways activated by leptin. Biochem J 393:7. https://doi.org/10.1042/BJ20051578

42. Li Z, Shen J, Wu WKK et al (2012) Leptin induces cyclin D1 expression and proliferation of human nucleus pulposus cells via JAK/STAT, PI3 K/Akt and MEK/ERK pathways. PLoS ONE 7:e53176. https://doi.org/10.1371/journal.pone.0053176

43. Tang C-H, Lu D-Y, Yang R-S et al (2007) Leptin-induced IL-6 production is mediated by leptin receptor, insulin receptor substrate-1, phosphatidylinositol 3-kinase, Akt, NF-kappaB, and p300 pathway in microglia. J Immunol 179:1292-1302. https:// doi.org/10.4049/jimmunol.179.2.1292 
44. Segar AH, Urban JPG, Fairbank JCT et al (2016) The Association Between Body Mass Index (BMI) and back or leg pain in patients with spinal conditions: results from the Genodisc Study. Spine 41:E1237-E1243. https://doi.org/10.1097/BRS.0000000000 001606

45. Fowler Brown A, Kim DH, Shi L et al (2015) The mediating effect of leptin on the relationship between body weight and knee osteoarthritis in older adults. Arthr Rheum 67:169-175. https:// doi.org/10.1002/art.38913

46. Karvonen-Gutierrez CA, Harlow SD, Mancuso P et al (2013) Leptin levels are associated with radiographic knee osteoarthritis among a cohort of mid-life women. Arthr Care Res 65:936-944. https://doi.org/10.1002/acr.21922

47. Stannus OP, Jones G, Quinn SJ et al (2010) The association between leptin, interleukin-6, and hip radiographic osteoarthritis in older people: a cross-sectional study. Arthr Res Ther 12:R95. https://doi.org/10.1186/ar3022

48. Staikos C, Ververidis A, Drosos G et al (2013) The association of adipokine levels in plasma and synovial fluid with the severity of knee osteoarthritis. Rheumatology (Oxford) 52:1077-1083. https ://doi.org/10.1093/rheumatology/kes422

49. Berry PA, Jones SW, Cicuttini FM et al (2011) Temporal relationship between serum adipokines, biomarkers of bone and cartilage turnover, and cartilage volume loss in a population with clinical knee osteoarthritis. Arthr Rheum 63:700-707. https://doi. org/10.1002/art.30182

50. Filková M, Lišková M, Hulejová H et al (2009) Increased serum adiponectin levels in female patients with erosive compared with non-erosive osteoarthritis. Ann Rheum Dis 68:295-296. https:// doi.org/10.1136/ard.2008.095737

51. Yusuf E, Ioan-Facsinay A, Bijsterbosch J et al (2011) Association between leptin, adiponectin and resistin and long-term progression of hand osteoarthritis. Ann Rheum Dis 70:1282-1284. https://doi. org/10.1136/ard.2010.146282

52. Choe J-Y, Bae J, Jung H-Y et al (2012) Serum resistin level is associated with radiographic changes in hand osteoarthritis: cross-sectional study. Joint Bone Spine 79:160-165. https://doi. org/10.1016/j.jbspin.2011.04.009

\section{Affiliations}

\section{Anand H Segar 1,2,3 - Jeremy C T Fairbank ${ }^{1,2}$ - Jill Urban ${ }^{3}$}

Anand H Segar

ahsegar@gmail.com

$1 \quad$ Nuffield Department of Orthopaedics, Rheumatology and Musculoskeletal Sciences, University of Oxford, Oxford, UK
53. Gosset M, Berenbaum F, Salvat C et al (2008) Crucial role of visfatin/pre-B cell colony-enhancing factor in matrix degradation and prostaglandin E2 synthesis in chondrocytes: possible influence on osteoarthritis. Arthr Rheum 58:1399-1409. https://doi. org/10.1002/art.23431

54. Théron J, Guimaraens L, Casasco A et al (2007) Lumbosacral liposuction. A new tool for the treatment of low back pain. Interv Neuroradiol 13:153

55. James G, Sluka KA, Blomster L et al (2018) Macrophage polarization contributes to local inflammation and structural change in the multifidus muscle after intervertebral disc injury. Eur Spine J 27:1744-1756. https://doi.org/10.1007/s00586-018-5652-7

56. Iwamoto J, Takeda T, Sato Y, Matsumoto H (2011) Serum leptin concentration positively correlates with body weight and total fat mass in postmenopausal japanese women with osteoarthritis of the knee. Arthritis 2011:1-6. https://doi.org/10.1002/art.10630

57. Shamsuzzaman ASM (2004) Independent association between plasma leptin and C-Reactive protein in healthy humans. Circulation 109:2181-2185. https://doi.org/10.1161/01.CIR.0000127960 .28627 .75

58. Presle N, Pottie P, Dumond H et al (2006) Differential distribution of adipokines between serum and synovial fluid in patients with osteoarthritis. Contribution of joint tissues to their articular production. Osteoarthr Cartil 14:690-695. https://doi.org/10.1016/j. joca.2006.01.009

59. Li Z, Yu X, Liang J et al (2014) Leptin downregulates aggrecan through the p38-ADAMST pathway in human nucleus pulposus cells. PLoS ONE 9:e109595. https://doi.org/10.1371/journ al.pone.0109595

60. Li Z, Shen J, Wu WKK et al (2013) The role of leptin on the organization and expression of cytoskeleton elements in nucleus pulposus cells. J Orthop Res. https://doi.org/10.1002/jor.22308

61. Sharma A (2018) The role of adipokines in intervertebral disc degeneration. Med Sci 6:34. https://doi.org/10.3390/medsci6020 034
2 Nuffield Orthopaedic Centre, Oxford Nuffield NHS Trust, Windmill Road, Oxford OX3 7HE, UK

3 Department of Physiology, Anatomy and Genetics, University of Oxford, Oxford, UK 